\title{
407 側方衝突時における自動車乗員の頚椎三次元挙動解析
}

Three Dimensional Analysis for Cervical Vertebrae Responses of Automobile Passengers

due to Lateral Impact

$\begin{array}{ccll}\text { 小林 } & \text { 英夫 } & \text { (東工大) } \\ \text { 正 小野 } & \text { 古志郎 } & \text { (日自研) } \\ & \text { 金岡 } & \text { 恒治 } & \text { (早大) } \\ & \text { 椎名 } & \text { 逸雄 } & \text { (筑波大) }\end{array}$

\author{
正 宇治橋 貞幸（東工大） \\ 正江島 晋 (日自研) \\ 福島 真（筑波メディカル）
}

Hideo KOBAYASHI : Tokyo Institute of Technology, 2-12-1, Oh-okayama, Meguro-ku, Tokyo

Sadayuki UJIHASHI : Tokyo Institute of Technology

Koshiro ONO, Susumu EZIMA : Japan Automobile Research Institute

Koji KANEOKA : University of Waseda

Makoto FUKUSHIMA : Tsukuba Medical Center

Itsuo SHIINA : University of Tsukuba

Key Words : Neck Injury, Cervical Spine, Three Dimensional Motion Analysis, Lateral Impact

\section{1. 緒言}

頚椎捻挫をはじめとする軽度の頚部傷害は自動車の後面 衝突事故によって発生することが多いと考えられてきたが， 側面衝突事故（以下「側方衝撃」とする）においてもかなり の頻度で発生することが報告されている(1). しかし，側方衝 撃に対する乗員の頚椎举動の衝撃応答に関する報告は少な く, 著者らのグループの先行研究 (山田ら ${ }^{(2)}$ ) による報告し か見当たらない。 また，屍体実験において側方衝撃に対し， 頚椎は側屈運動の他に回旋, 屈曲-伸展運動を伴う三次元挙 動を示すことが報告されている ${ }^{(3)}$. しかし，乗員の頚椎举動 は前額面内の二次元解析しか行われておらず, 三次元解析を 行った研究は見当たらない.そこで本研究では側方衝撃時の 頚椎三次元挙動を把握するために，山田ら (2)により行われた 実験で撮影されたシネ画像を解析し，頚椎の相対的な三次元 回転角を算出した. そして, 志願者の自動的な側屈における 頝椎挙動 (自動挙動) と, 衝撃を負荷した強制的な側屈にお ける頝椎挙動を比較し, 側方衝撃における三次元解析の重要 性を示し，さらにこの解析によって傷害が惹起されやすい部 位について考察を行った.

\section{2. 志願者による肩部側方衝擊実験}

山田ら ${ }^{(2)}$ の側方衝撃実験において，志願者は䅡部傷害の既 往症のない健常成人 6 名（男性 4 名, 女性 2 名）である。実 験の概要を再掲すると次のとおりである.図1に示すように 志願者をシートに着座させ, 空気圧縮式のインパクタにより 志願者の肩部に対して右側方から衝撃を加えた. 頚椎挙動を 記録するために X 線シネ撮影装置 (Philips BH5000 : 60fps) を用いて図 2(a)に示すような経時的なシネ画像を記録した。 また，図 3(a),(c)に示す前額面および矢状面の静止 X 線画像 の撮影も行った．実験条件は，筋緊張の有無についても調心゙ るとともに, 衝撃荷重 $300 \mathrm{~N}, 400 \mathrm{~N}, 500 \mathrm{~N}$ の 3 段階強度の衝撃 を負荷した. なお, 男性志願者では $600 \mathrm{~N}$ の衝撃負荷も追加 した.

\section{3. 晅椎三次元挙動の解析手法}

実験によって得られたシネ画像から各志願者の第 5〜7 頚 椎，第 1 胸椎（以下「C5 C7,T1」とする）の回転角を算出す るために, 各頝椎に図 3(b)のような特徴点を 3 点定義し, 特 徵点はそれぞれ(1)：右椎弓根中央,(2)：左椎马根中央,(3)：棘 突起下端とした. 矢状面において点(1)および点(2)は判別が困 難なため, それらの点を椎体後縁（図 3 中緑点線上）に位置 すると仮定した。これらの3 点間距離を仮定と前額面および 矢状面静止 $\mathrm{X}$ 線画像より算出した. 次に 3 点間距離および図 2(a)に示すシネ画像内の特徴点 3 点の二次元座標より, 3 点 の相対的な三次元座標を算出し, 各頚椎に点(3)を原点とする 局所座標系を図 2(b),(c)のように定義した。なお，局所座標 系は点(3)から点(1)および点(2)の中点へのベクトル $\boldsymbol{a}$ と点(1)か ら点(2) へのベクトル $\boldsymbol{b}$ を用いて $, x, y, z$ 軸の単位ベクトル $\boldsymbol{i}, \boldsymbol{j}, \boldsymbol{k}$ を式(1)のように定義した.

$$
\begin{aligned}
& \boldsymbol{i}=\boldsymbol{j} \times \boldsymbol{k} \\
& \boldsymbol{j}=\boldsymbol{k} \times \boldsymbol{b} /|\boldsymbol{b}| \\
& \boldsymbol{k}=\boldsymbol{a} \times \boldsymbol{b} /|\boldsymbol{a} \times \boldsymbol{b}|
\end{aligned}
$$

そして, 局所座標系を $z, y, x$ 軸回りの順に回転させる Cardan Angle を用いて，500N および $600 \mathrm{~N}$ の非緊張の試技と自動挙動の下 位䅡椎に対する相対三次元回転角を算出した。

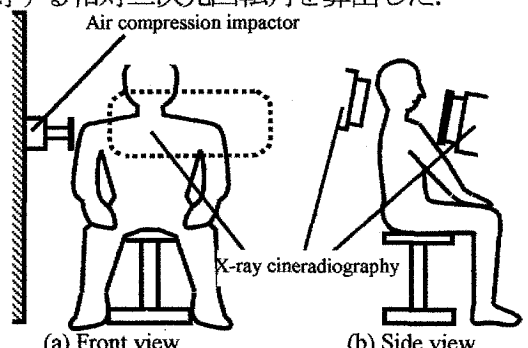

Fig.1 Frontal and lateral views of experimental apparatus

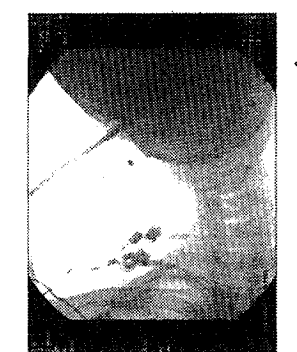

(a) Contimuous $\mathrm{X}$-ray images

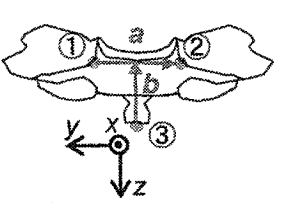

(b) Frontal view

(1),(2)

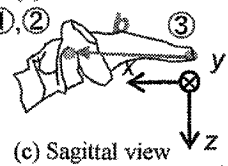

Fig.2 Definition of local coordinate system

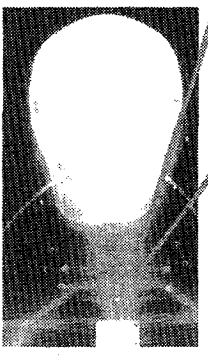

(a) Frontal X-ray

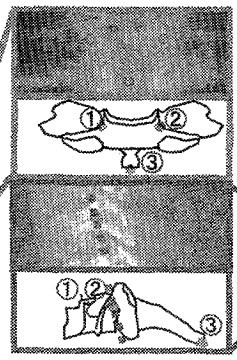

(b) Feature points

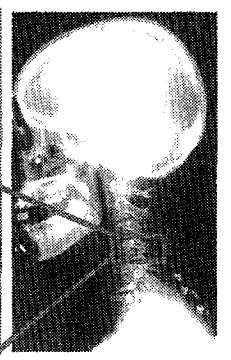

(c) Sagittal X-ray
Fig. 3 Definition of three feature points in frontal and sagittal X-ray images 


\section{4. 結果および考察}

\section{(1)自動挙動と衝㨌時における难椎挙動の比較}

自動挙動(Active)と衝撃時の頚椎举動を比較するために各 志願者の $\mathrm{C} 6 / \mathrm{C} 7, \mathrm{C} 7 / \mathrm{T} 1$ の三次元回転角平均値を図 4 に示寸. 試技 $500 \mathrm{~N}$ で忟図 4(c)に示す $\mathrm{C} 6 / \mathrm{C} 7$ において $x$ 軸の回転角が 図 4(a)に示自動挙動を上回り, $y$ 軸 (70ms 以降) と $z$ 軸 $(90 \mathrm{~ms}$ 以降）の回転方向が自動挙動と逆転する傾向を示した. 図 4(d)に示す C7/T1 では $z$ 軸 (50ms 80ms) の回転方向が図 4(b) に示す自動挙動と逆転する傾向を示した.この傾向は Panjabi ら (3)により行われた屋体実験においても確認されている。 た，同実験において衝撃を負荷した方向の反対側の関節包勒 帯が裂けたと報告されていることから，関節包勒帯に極度の 引張が作用したと考えられる，そのため，逆転する傾向は衝 撃前の姿勢で前方 $(x$ 軸正方向 $)$ に傾斜している関節包勒带, 横突起勒带が衝撃により大きな引張をうけ, $z$ 軸と平行な直 線上に並ぶ様に頝椎が回転したため生じたと考えられる．ま た，この傾向は C7/T1,C6/C7 の順であった.これは衝撃が有 より入力され, 体幹, 下位頚椎, 上位頚椎の順で伝わるため と考えられる.試技 $600 \mathrm{~N}$ では図 4(e)に示す C6/C7 において $y, z$ 軸 (100ms 以降) の回転方向が逆転する傾向を示し, 図 4(f)に示す C7/T1 では $x$ 軸の回転角が自動挙動を上回り， $z$ 軸では回転方向が自動挙動と一致した. 頚椎の側屈と回旋の 複合運動はくさび状の椎間板, 左右の椎間関節のすべりによ り生じると考えられている ${ }^{(4)}$.このことから, $600 \mathrm{~N}$ の C7/T1 で $z$ 軸の回転方向が自動挙動と一致した傾向は, 衝撃により $x$ 軸において自動挙動を上回る回転が急激に生じ，右椎間関 節が圧縮され，強制的に自動挙動と同じ方向に椎体が回転し たため生じたと考えられる.このように頚椎が自動挙動を上 回る側屈を示す領域においては，衝撃の程度により屈曲-伸 展, 回旋の回転方向が逆転することがある.このような現象 を把握する上でも頚椎の三次元挙動の解析は必要である.

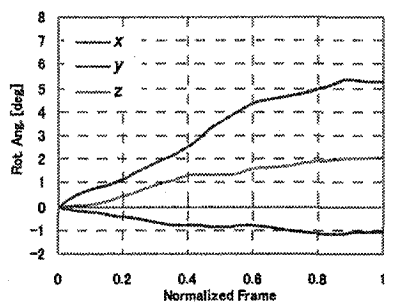

(a) $\mathrm{C} 6 / \mathrm{C} 7$ (Active Lateral Bending)

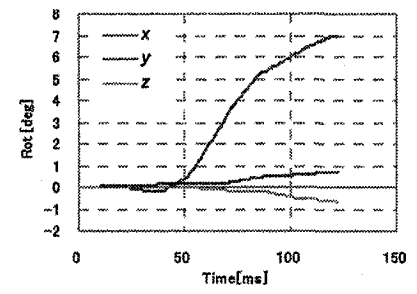

(c) $\mathrm{C6} / \mathrm{C} 7(500 \mathrm{~N})$

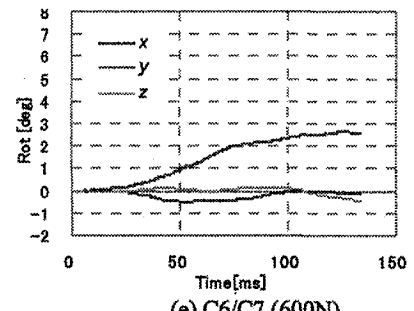

(e) $\mathrm{C} 6 / \mathrm{C} 7(600 \mathrm{~N})$
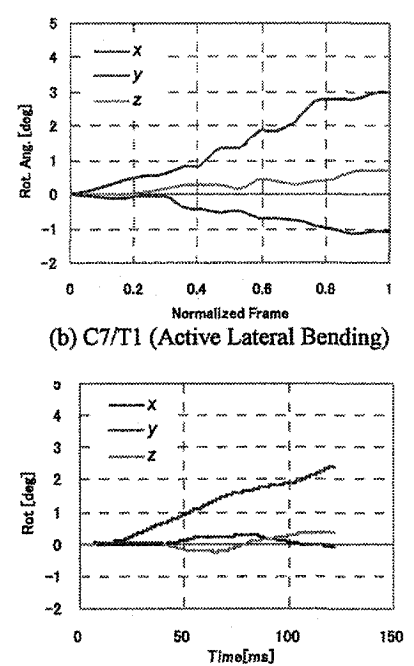

(d) $\mathrm{C} 7 / \mathrm{T} 1(500 \mathrm{~N})$

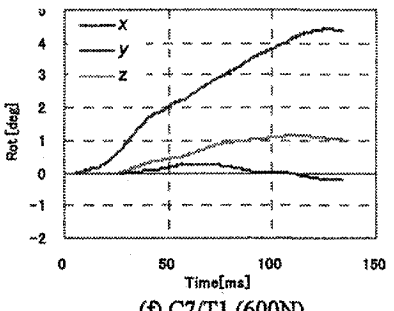

(f) $\mathrm{C} 7 / \mathrm{TI}(600 \mathrm{~N})$ (b) C7/T1 (Active Lateral Bending)

Fig.4 Three-dimensional cervical vertebrae rotational angles

\section{(2)IV-NICによる評価}

各頚椎について衝撃負荷により生じた右側屈回転角 $(x$ 軸 回り)の定量的な比較を Panjabi らにより提唱されている傷害 指標 IV-NIC ${ }^{(3)}$ により行った. IV-NIC は衝撃時の頚椎回転角を自 動挙動の頝椎回転角で除すことにより算出した. 算出した各 志願者の C5/C6,C6/C7,C7/T1 の IV-NIC を図 5 に示す. 図 5(a) に示す試技 $500 \mathrm{~N}$ では志願者 5 を除く全ての志願者において

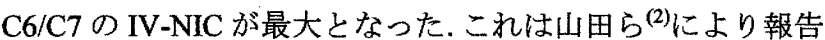
された同実験の二次元解析結果と一致している，側方衝撃は 肩より入力され，体幹，下位頚椎，上位頚椎，頭部の順に伝わる. そのため下位頚椎ほど回転角, IV-NIC が大きくなり， C7/T1 で 最大となると考えられる。しかし，500N では C6/C7 の IV-NIC が最大となった。これは C5/C6,C7/T1 の IV-NIC が大きいため, 衝擊が C5/C6〜C7/T1 で分散していると考えられること，さらに $\mathrm{C} 7 / \mathrm{T} 1$ は他の部位と比べると可動範囲もせまく側屈しにくいこと から，C6/C7が大きく回転したと考えられる. 図 5(b)に示す試技 600N では C6/C7 の IV-NIC は 500N に対して減少し, C7/T1 の IV-NIC が最大となった. $600 \mathrm{~N}$ で待衝撃が増加したことによ り，下位頚椎から伝わる衝撃が分散せずにC7/T1 に集中し, IV-NIC が最大になったと考えられる。試技 $500 \mathrm{~N}$ の C6/C7, 試技 $600 \mathrm{~N}$ のC7/T1 において最大となる IV-NIC は共に1を超えており， 頚椎の側屈が自動挙動における側屈を上回ることを示して いる.これらの下位頚椎(C6/C7,C7/T1)において IV-NIC が最 大となる傾向は, 側方衝突事故時の頚部傷害が頚部下位に集 中すると言われる臨床的な知見と一致している.このことよ り，C6/C7,C7/T1 における椎間板，椎間関節に極度の圧縮， 引張が作用し，頝部傷害が惹起されやすいと考えられる.

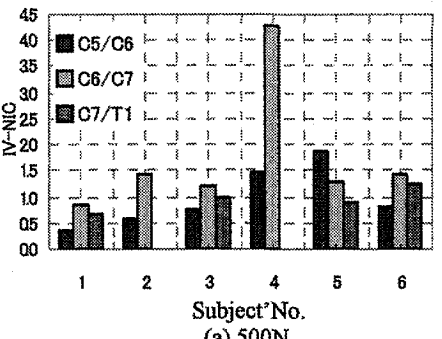

(a) $500 \mathrm{~N}$

\section{5. 結言}

Fig. 5 Comparison of IV-NIC

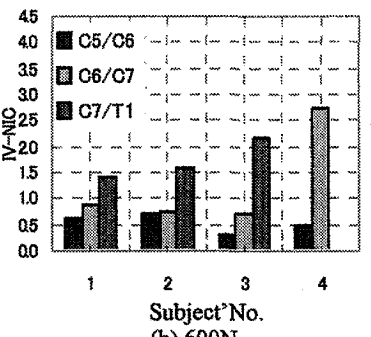
(b) $600 \mathrm{~N}$
志願者実験より得られたシネ画像の三次元解析を行い, C5/C6-C7/T1 の下位頚椎に対する相対三次元回転角を算出した. 自動挙動と衝撃時の頚椎挙動を比較し，頚椎が自動挙動を上回る 側屈を示す領域において，衝撃の程度により屈曲-伸展，回旋の回 転方向が逆転する傾向を明らかにし，側方衝撃時における㸚椎三 次元挙動解析の重要性を示した. また，衝撃を負荷した強制的 な右側屈において衝撃の強度が $500 \mathrm{~N}$ から $600 \mathrm{~N}$ に増加すると, IV-NIC が最大となる部位が C6/C7 から C7/T1 と変化する傾向を明 らかにした.

\section{参考文献}

（1）（財）交通事故総合分析センター,H16 年度交通事故調 查・分析報告書,III-4-3,461-464,平成 17 年 3 月発行

(2) 山田新太郎,側方衝擊時における乗員の頭部・頝部・体幹の挙 動解析,76-81, 平成 18 年度 修士論文

(3) MANOHAR M.PANJABI and PAUL C.IVANCIC,'Intervertebral Neck Injury Criterion for Prediction of Multiplanar Cervical Spine Injury Due to Side Impacts",Traffic Injury Prevention,6,390-392,2005

(4) I.A.KAPANDI,"カパンディ関節の生理学”, 医茵薬出版株式会 社,194-195,1998 